Three Minute Article for Parents

\title{
Improving standards of care for children with thalassaemia in Sri Lanka
}

\author{
Sachith Mettananda (D) https://orcid.org/0000-0002-0760-0418
}

Sri Lanka Journal of Child Health, 2020; 49(1): 94

DOI: http://dx.doi.org/10.4038/sljch.v49i1.8911

(Key words: Standard of care, children, thalassaemia, Sri Lanka)

Thalassaemia is a common genetic disease affecting red blood cells of humans. It is particularly common in tropical countries in South and South-East Asia. Children with severe thalassaemia develop severe anaemia (reduction of haemoglobin in red blood cells) during infancy and require frequent blood transfusions throughout their lives. During the past few years, we performed a series of research studies to evaluate the standards of care for children with thalassaemia in Sri Lanka.

Firstly, we did a countrywide survey to obtain accurate information on the number of patients with thalassaemia living in Sri Lanka ${ }^{1}$. This survey revealed that there are 1774 thalassaemia patients receiving treatment from 23 hospitals spread across Sri Lanka. The highest were attending thalassaemia centres of Kurunegala (755), Ragama (302) and Anuradhapura (242). Most (68\%) patients in Sri Lanka had the disease type beta-thalassaemia major whereas $20 \%$ had haemoglobin $\mathrm{E}(\mathrm{HbE})$ betathalassaemia, a subtype of beta-thalassaemia.

Next, we evaluated the provision of blood transfusions to patients with thalassaemia. We examined the adequacy of transfusions in 328 thalassaemia children receiving treatment from Kurunegala, Ragama and Anuradhapura hospitals ${ }^{2}$. This revealed proper guidelines to perform blood transfusions in patients with beta-thalassemia major. However, uniform recommendations were lacking to guide blood transfusions in patients with $\mathrm{HbE}$ beta-thalassaemia. Thus, patients with $\mathrm{HbE} \beta$ thalassaemia received suboptimal transfusions and were anaemic. Based on this, we recommended intensifying blood transfusions for patients with $\mathrm{HbE}$ beta-thalassaemia throughout the country.

Iron overload is an inevitable complication of thalassaemia. Most patients have high levels of iron in the body which gets deposited in their hearts and livers leading to dysfunction. To counteract it, thalassaemia patients are given medicines to remove excess iron from the body ('iron chelator medication'), usually after ten blood transfusions. In our next study, we evaluated the control of iron overload among thalassaemia children ${ }^{3}$. We found that the severity of iron overload has decreased from 2011 to 2017 showing improvement in care. However, in most patients, iron overload rapidly increased during the second year of life when they were not receiving 'iron chelator medication'. Thus we recommended commencing 'iron chelator medication' after 5-6 blood transfusions.

Finally, we assessed the quality of life (QOL) among thalassaemia children ${ }^{4}$. This revealed that despite improvements in treatment, QOL remains low among beta-thalassaemia patients, particularly among $\mathrm{HbE}$ beta-thalassaemia patients. Thus, we proposed that health care providers should take active steps to improve the QOL among betathalassaemia patients. We believe that the recommendations derived through our research will help uplift the standards of care of thalassaemia patients in Sri Lanka and even globally.

\section{References}

1. Premawardhana AP, Mudiyanse R, De Silva ST, et al. A nationwide survey of hospital-based thalassaemia patients and standards of care and a preliminary assessment of the national prevention programme in Sri Lanka. PloS one 2019; 14(8):e0220852.

2. Mettananda S, Pathiraja H, Peiris R, Wickramarathne $\mathrm{N}$, et al. Blood transfusion therapy for beta-thalassaemia major and haemoglobin E betathalassemia: Adequacy, trends, and determinants in Sri Lanka. Pediatric Blood \& Cancer 2019; 66(5): 27643.

3. Suriapperuma T, Peiris R, Mettananda C, Premawardhena A, Mettananda S. Body iron status of children and adolescents with transfusion dependent betathalassaemia: trends of serum ferritin and associations of optimal body iron control. BMC Research Notes 2018; 11(1):547.

4. Mettananda S, Pathiraja H, Peiris R, Bandara D, et al. Health related quality of life among children with transfusion dependent beta-thalassaemia major and haemoglobin E beta-thalassaemia in Sri Lanka: a case control study. Health and Quality of Life Outcomes 2019; 17(1):137.

Open Access Article published under the Creative Commons Attribution CC-BY (c) (†) License 